\title{
Toxicological Risk Assessment of the Accidental Ingestion of a Honeybee (Apis mellifera L.) Present in Food
}

\author{
Jéssica Baeça Rezende Marinho and Benito Soto-Blanco* \\ Department of Veterinary Clinics and Surgery, Veterinary College, Universidade Federal de Minas Gerais (UFMG), Belo \\ Horizonte, Brazil
}

The aim of the present work was to evaluate the possible risk of toxic effects due to the ingestion of a honeybee (Apis mellifera L.) accidentally present in food. The methodology used in this study was a bibliographic survey of studies on the toxic effects related to honeybees, with a critical analysis of the possible risks of accidental ingestion of these insects. The amount of venom present in a bee is considered insufficient to induce detectable toxic effects in a person who ingests it by accident, and various components of the venom are destroyed by gastric secretions. However, despite the rare frequency, there is a risk of the ingestion of a bee, causing an allergic reaction to some components of the venom in sensitized individuals. In addition, pollen carried by a bee may cause an

OPEN ACCESS

Edited by:

Simone Mancini,

University of Pisa, Italy

Reviewed by:

Samuel Ayofemi Olalekan Adeyeye, Ton Duc Thang University, Vietnam

Robert Musundire, Chinhoyi University of Technology, Zimbabwe

*Correspondence: Benito Soto-Blanco benito@ufmg.br

Specialty section: This article was submitted to Animal Nutrition and Metabolism,

a section of the journal

Frontiers in Veterinary Science

Received: 14 July 2020

Accepted: 25 August 2020

Published: 30 September 2020

Citation:

Marinho JBR and Soto-Blanco $B$ (2020) Toxicological Risk Assessment of the Accidental Ingestion of a Honeybee (Apis mellifera L.) Present in

Food. Front. Vet. Sci. 7:583286.

doi: 10.3389/fvets.2020.583286 allergic reaction in a sensitive individual. Thus, the accidental ingestion of a bee present in a food does not pose the risk of toxic effects for the majority of the population but may promote allergic reactions in susceptible individuals.

Keywords: accidental ingestion, allergens, honeybee, toxicological hazard, venom, zootoxins

\section{INTRODUCTION}

Honeybees (Apis mellifera L.) are social insects bred for the production of honey, pollen, propolis, royal jelly, wax, and poison, and to promote the pollination of various cultivated plant species. These bees have a sting as their defense mechanism, through which their venom is inoculated $(1,2)$. As honeybees seek products with sugar as their food source, they may end up trapped and incorporated into food (Figure 1), and potentially consumed inadvertently. A number of anecdotal reports of accidental ingestion of insects are largely available (3-6), but the actual number remains unknown.

The intentional consumption of insects by humans, known as entomophagy, is a habit of many populations around the world. Entomophagy has been advocated as a way to increase the availability of foods of recognized nutritional value (7). In the case of honeybees, they are traditionally eaten roasted or grilled in countries such as Japan, China, and Indonesia (8). Thus, it is possible that the heat used in the preparation methods may denature any harmful substances present.

However, there is a lack of information in the literature on the toxicological risks arising from the ingestion of raw honeybees. Thus, the aim of the present work was to evaluate the possible risk of toxic effects due to the ingestion of a honeybee accidentally present in food. The methodology used in this study was a bibliographic survey of studies on the toxic effects related to honeybees, with a critical analysis of the possible risks of accidental ingestion of these insects. The possibility that the ingested insect may carry a microorganism with the potential to cause infection was not addressed in this study. 


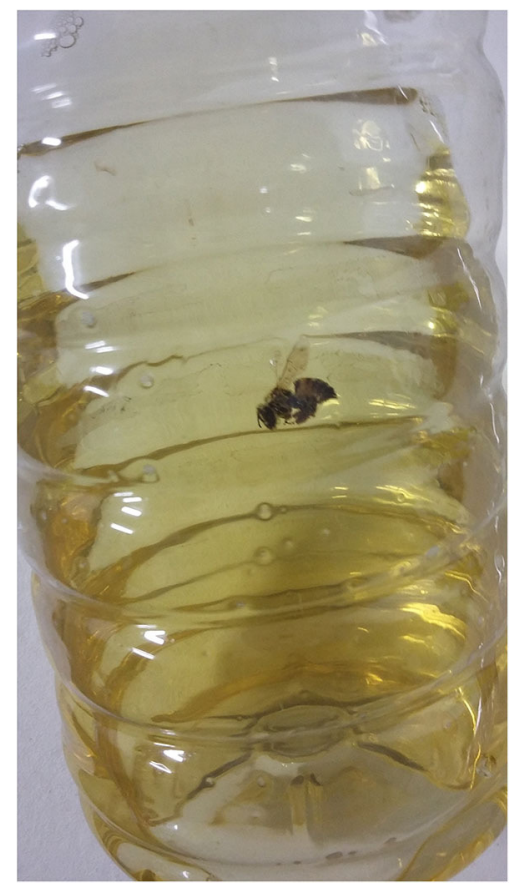

FIGURE 1 | Honeybee trapped in an orange-flavored drink.

\section{THE HONEYBEE VENOM}

The honeybee sting is a defensive mechanism against predator attacks on individuals or hives (9-11). The stinger is a modification of the reproductive apparatus and is present only in worker honeybees. The venom, also known as apitoxin, is produced by venom gland cells and is injected at the time of the sting. When the stinger is introduced, it becomes trapped with the venom sac at the sting site and gradually releases the venom $(10,12,13)$.

Honeybee venom is composed of peptides, including melittin, apamin, and mast cell degranulating peptide (MCDP), the enzymes phospholipase $\mathrm{A}_{2}$ and hyaluronidase, and biogenic amines (histamine, dopamine, and noradrenaline) $(10,12,14,15)$ (Table 1). Many other compounds were identified in the venom, but they are unlikely to possess toxicological importance.

The peptide melittin is the most abundant toxin in honeybee venom, comprising $\sim 40$ to $60 \%$ of the dry weight of this venom, consisting of a basic 26-amino-acid polypeptide $(12,15$, 16). Melittin monomers bind to lipid membranes producing pores, exerting a cytotoxic effect $(17,18)$. Furthermore, it acts synergistically with the enzyme phospholipase $\mathrm{A}_{2}$, promoting damage to the cellular and mitochondrial membranes of various cell types. Arachidonic acid may be released because of cell damage $(10,15)$. This peptide is probably the major responsible for the bee venom-induced pain through direct and indirect activation of primary nociceptor cells (16). As melittin has various pharmacological activities, including antitumoral (15, 19), anti-viral $(18,18,20)$, antibacterial $(15,17)$, antifungal
TABLE 1 | Main components of honeybee (Apis mellifera) venom (10, 12, 14, 15).

\begin{tabular}{ll}
\hline Chemical groups & Compounds \\
\hline Peptides & Melittin \\
& Apamin \\
& Mast cell degranulating peptide (MCDP) \\
& Other peptides \\
Enzymes & Phospholipase $\mathrm{A}_{2}$ \\
& Hyaluronidase \\
Biogenic amines & Histamine \\
& Serotonin \\
& Dopamine \\
& Noradrenaline
\end{tabular}

(15), anti-arthritis, anti-inflammatory, anti-atherosclerotic, antidiabetic, and neuro-protective (12) effects, several studies have been conducted to evaluate the safety of the compound when administered orally. The results of these studies indicate that oral ingestion of this peptide results in low toxicity (21-23).

Apamin is a peptide neurotoxin comprising 2 to $3 \%$ of dry honeybee venom. This peptide is a specific inhibitor of small-conductance $\mathrm{Ca}^{2+}$-activated $\mathrm{K}^{+}(\mathrm{SK})$ channels in the central nervous system $(13,15)$ and activates the $\mathrm{M}_{2}$ inhibitory muscarinic receptors of the peripheral nervous system $(10,14,15)$. Another activity is blockage of the Kv1.3 channel, a potassium channel type found in immune cells (24). Pharmacologically, apamin has antibacterial, antifungal, anti-inflammatory, anti-atherosclerotic, and antitumoral effects (13) and has been tested for treating neurological disturbances, including Parkinson's disease and learning deficit disorder (15).

The main enzymes present in the venom are phospholipases and hyaluronidase Phospholipase $\mathrm{A}_{2}$, comprises $10 \%$ to $12 \%$ of dry bee venom, promotes the disruption of the cytoplasmic membrane by the destruction of the constituent phospholipids, resulting in cell lysis $(10,14,15,25)$. This enzyme catalyzes the hydrolysis of glycerophospholipids, releasing fatty acids and lysophospholipids (25). P was also found to have antibacterial, trypanocidal, antitumoral, neuroprotective, and hepaprotective activities (15).

The other enzyme found in honeybee venom is hyaluronidase, which comprises 1 to $3 \%$ of venom. This enzyme promotes the fast tissue diffusion of venom through tissue disruption. Hyaluronidase causes the hydrolysis of hyaluronic acid in the extracellular matrix $(10,13-15)$. Other activities of hyaluronidase include mast cell degranulation and rise in blood vessel permeability (13).

Phospholipases and hyaluronidase are the allergenic proteins in the venom, being responsible for cases of anaphylactic reaction to honeybee venom $(13,15,26)$. The enzyme phospholipase $A_{2}$, isolated from microorganisms and vertebrate animals, is used in the processing of certain foods, and it has been experimentally verified that the consumption of phospholipase $A_{2}$ residues does not represent a toxicological risk $(27,28)$. However, some cases of allergic reactions to honeybee phospholipase $\mathrm{A}_{2}$ residues 
present in honey consumed by sensitized individuals have been identified (29).

The peptide MCDP acts on mast cells, promoting degranulation releasing histamine, and consequent inflammation $(13,15)$. Paradoxically, large amounts of MCDP inhibits the release of histamine by mast cells (15). It also blocks fast activation and slowly inactivating $\mathrm{K}+$ channels, resulting in neuronal hyperexcitability (30).

The biogenic amines present in honeybee venom are histamine, dopamine, and noradrenaline. Histamine, which amount present in the venom is smaller than that released by MCDP, promotes vasodilation enhancing the inflammation, whereas noradrenaline and dopamine have a well-known ionotropic effect $(10,13,15)$. The ingestion of biogenic amines present in the honeybee venom sac probably does not represent a significant toxicological risk, because these amines are present in amounts that are high enough to impact human health $(31,32)$.

Honeybees can sting only once, leaving the stinger and venom sac in the sting site. A sting by one or a few honeybees promotes a reaction at the sting site that begins quickly and is characterized by pain, edema, and erythema. These local effects usually last for hours, but may, in some cases, continue for days. Multiple honeybee stings (a minimum of one hundred) are capable of promoting a systemic toxic reaction, characterized by agitation, vomiting, diarrhea, difficulty breathing, seizures, hyperthermia, and shock. Other clinical effects of the systemic toxic reaction are rhabdomyolysis and heart failure. In addition, sensitized individuals, who have been previously exposed to honeybee venom, may exhibit an anaphylactic reaction after only a single sting $(33,34)$.

A rare effect promoted is myocardial infarction, which usually occurs after multiple honeybee stings (35-38), but has also been observed as a result of only one sting (39). It is likely that myocardial infarction is caused by the spasm or thrombosis of the coronary arteries $(39,40)$ or is secondary to the hypersensitivity reaction (38).

It has been estimated that the amount of venom from honeybees that is lethal to $50 \%$ of humans by injection is $2.8 \mathrm{mg}$ venom per $\mathrm{kg}$ of body weight. As a honeybee yields about 160 $\mu \mathrm{g}$ of venom (11), this amount is insufficient to cause detectable toxic effects in a person who has only ingested a single insect. In addition, as reported, various components of the venom are destroyed by gastric secretion. In addition, honeybee venom used for medical purposes is administered only by injection (41-43), rather than orally, most likely because it would lose its activity owing to degradation by the digestive system.

Remarkably, honeybee venom can cause allergic reactions in sensitized individuals (44-46). It has been found that even residual amounts of honeybee venom in honey can induce an allergic reaction, which is a very rare condition $(29,47)$. These allergic reactions are triggered mainly by the peptide melittin and the enzymes phospholipase $A_{2}, A_{1}$, and hyaluronidase. Allergic reactions to poison can be identified by the production of specific $\operatorname{IgE}$ and IgG4 antibodies in the serum of patients (48). Thus, although it is a rare condition, there is the risk that the ingestion of a honeybee may induce an allergic reaction to some venom components in sensitive individuals. In addition, the structural proteins of the honeybee itself may also induce an allergic reaction (47).

\section{POLLEN}

Honeybees are pollinating insects that collect pollen grains when visiting the flowers used for their food. The pollen grains collected by honeybees are agglutinated and transported to their colony in structures present in the hind legs named corbicles or pollen baskets. In addition, pollen grains also stick to the bee's body (49-51). In addition, to provide nutrients to bees, pollen serves as a source of enzymes that aid in the digestion of nutrients, such as beta-galactosidase, and helps to establish the beneficial digestive microbiota of these insects (52). For humans, pollen is a bee product known for its pharmacological activities, which include antimicrobial, anti-viral, antiinflammatory, immunostimulatory, and antioxidant effects $(53,54)$.

The ingestion of pollen collected by honeybees may be responsible for the development of acute allergic reactions, including anaphylaxis, in sensitized individuals. Honeybee secretions probably do not significantly reduce the allergenic potential of the collected pollen (55). Although relatively rare, allergic reactions to pollen can be quite severe, even lethal (55-60). This reaction occurs after previous exposure to the compound that causes the reaction in the sensitized individual that usually does not occur at first exposure.

A large number of plant species may cause allergic reactions to pollen (Table 2). Thus, the pollen from several plant species that is collected by honeybees can cause allergic reactions in humans (60). Importantly, the same patient may have allergic reactions to pollen from more than one plant species simultaneously (58, 61,62 ). In addition, patients who have allergic reactions to pollen may not be hypersensitive to honeybee venom components (61).

The allergic reactions to pollen occur after previous sensitization to their allergens. Pollen allergens are trapped and processed by dendritic cells that migrate to lymph nodes and induce the differentiation of naïve $\mathrm{T}$ helper cells into Th2 cells. The contact of epithelial barrier organs to pollen allergens can induce epithelial cells to release interleukin (IL) 25, IL-33 thymic stromal lymphopoietin. These factors re-activate Th2 cells that release IL-4, IL-5, and IL-9. IL-4 stimulates B cells to produce and release antigen-specific IgEs, whereas IL-5 activates eosinophils. Furthermore, IL- 4 and IL-9 promote mast cell degranulation, releasing a number of compounds, including histamine, leukotrienes, cytokines, and chemotactic molecules, resulting in the clinical signs of allergic reaction (74).

A honeybee can carry more than $15 \mathrm{mg}$ of pollen (75). In addition, pollen is also present within the digestive tract of a bee; a study evaluating two hives found that each honeybee contained, on average, 3.35 and $4.27 \mathrm{mg}$ (76). It was found that one gram of pollen can contain between 400,000 and 6.4 million pollen grains (57). Patients exhibiting an allergic reaction after pollen consumption had a positive skin sensitivity test to $0.1 \mathrm{mg} / \mathrm{mL}$ 
TABLE 2 | Components of honeybee (Apis mellifera) venom.

\begin{tabular}{|c|c|c|c|}
\hline Common name & Scientific name & Plant family & References \\
\hline Chrysanthemum & Chrysanthemum spp. & Asteraceae & (61) \\
\hline Dandelion & Taraxacum spp. & Asteraceae & $(58,61)$ \\
\hline Ragweed & Ambrosia spp. & Asteraceae & $(61,62)$ \\
\hline Birch & Betula spp. & Betulaceae & $(63,64)$ \\
\hline Oak & Quercus spp. & Fagaceae & $(68,69)$ \\
\hline Ash & Fraxinus spp. & Oleaceae & $(69,70)$ \\
\hline Olive & Olea spp. & Oleaceae & $(58,71)$ \\
\hline Privet & Ligustrum spp. & Oleaceae & (71) \\
\hline Bahiagrass & Paspalum notatum & Poaceae & $(71,72)$ \\
\hline Reed canary grass & Phalaris arundinacea & Poaceae & (71) \\
\hline Tall fescue & Festuca arundinacea & Poaceae & (71) \\
\hline Ryegrass & Lolium perenne & Poaceae & $(58,62)$ \\
\hline London planetree & Platanus $\times$ acerifolia & Platanus & (58) \\
\hline Willows & Salix spp. & Salicaceae & (69) \\
\hline Elms & Ulmus spp. & Ulmaceae & (69) \\
\hline Nettle & Urtica spp. & Urticaceae & (69) \\
\hline
\end{tabular}

pollen extracts $(53,54)$. Thus, pollen carried by a bee may cause an allergic reaction in a sensitized individual.

Pollen may contain toxic substances produced by plants (77-81), notably, pyrrolizidine alkaloids (82-86). These alkaloids have potent hepatotoxic effects and cytotoxic, genotoxic, and oncogenic activities; some compounds also have neurotoxic and nephrotoxic effects $(87,88)$. A study in Germany revealed that a total of 17 out of 55 pollen samples collected by honeybees and marketed in Europe contained detectable levels of pyrrolizidine alkaloids, with concentrations ranging from 1.08 to $16.35 \mu \mathrm{g} / \mathrm{g}$ (85). On the assumption of the volume of pollen carried by a honeybee as $15 \mathrm{mg}$ (76), the amount of pyrrolizidine alkaloids ranging from 16.2 to $245.25 \mathrm{ng}$. As the ingestion of pyrrolizidine alkaloids up to $0.1 \mu \mathrm{g} / \mathrm{kg}$ per day is considered safe for humans $(84,86)$, the probable amounts found in a honeybee should not pose any toxicological risk.

Pollen may also contain pesticide residues used in agriculture (89-92). The highest residual pesticide concentration found in pollen collected by honeybees in a study conducted in the United States was $16.556 \mu \mathrm{g} / \mathrm{g}$ of the pesticide phosmet (89). Again, assuming the volume of pollen carried by a bee as $15 \mathrm{mg}$ (75), this would be a maximum phosmet concentration of 248.34 ng, which would not pose a toxicological risk to humans as the

\section{REFERENCES}

1. Landim CC. Abelhas: Morfologia e Função de Sistemas. São Paulo, Brazil: Editora Unesp. (2009). p. 408. doi: 10.7476/9788539304301 acceptable daily intake for this compound has been set at $5 \mu \mathrm{g} / \mathrm{kg}$ body weight (93).

\section{CONCLUSIONS}

The amount of venom present in a honeybee is considered insufficient to cause detectable toxic effects on a person who has accidentally ingested it; moreover, components of the honeybee venom are destroyed by gastric secretion. In contrast, despite the rarity, there is a risk of honeybee ingestion, causing an allergic reaction to some component of the venom in sensitized individuals. In addition, pollen carried by a honeybee may cause an allergic reaction in a sensitized individual. Thus, the accidental ingestion of a honeybee present in food does not carry a risk for the production of toxic effects for the majority of the population but may promote allergic reactions in susceptible individuals.

\section{AUTHOR CONTRIBUTIONS}

BS-B conceived the paper. JM and BS-B wrote the manuscript. All authors contributed to manuscript revision, read, and approved the submitted version.

2. Soto-Blanco B. Medicamentos utilizados em apicultura. In: Spinosa HS, Palermo-Neto J, Górniak SL, editors. Medicamentos em Animais de Produção. Rio de Janeiro, Brazil: Guanabara Koogan (2014). p. 364-7. 
3. Soloway RAG. Eating Bugs. (2011). Available online at: https://www.poison. org/articles/2011-jun/eating-bugs (accessed May 22, 2020).

4. Mitchell H. Should You Worry if You Accidentally Swallow an Insect? (2015). Available online at: https://www.wsj.com/articles/should-you-worry-if-youaccidentally-swallow-an-insect- 1438010908 (accessed May 22, 2020).

5. Kinyuru J. Why Worry if You Accidentally Swallow an Insect? (2017). Available online at: https://insecthunter.wordpress.com/2017/01/13/whyworry-if-you-accidentally-swallow-an-insect (accessed May 22, 2020).

6. Sluck S. Swallowed a Bug? Here's What You Need to Know. (2018) Available online at: https://www.geisinger.org/health-and-wellness/wellnessarticles/2018/07/31/14/57/swallowed-a-bug-heres-what-you-need-to-know (accessed May 22, 2020).

7. Shelomi M. Why we still don't eat insects: assessing entomophaghy promotion through a diffusion of innovations framework. Trends Food Sci Technol. (2015) 45:311-8. doi: 10.1016/j.tifs.2015.06.008

8. Gahukar RT. Entomophagy and human food security. Int J Trop Insect Sci. (2011) 31:129-44. doi: 10.1017/S1742758411000257

9. Silveira DC, Maracajá PB, Silva RA, Sousa RM, Soto-Blanco B. Variações diurna e sazonal da defensividade das abelhas africanizadas (Apis mellifera L.). Rev Bras Saúde Prod Anim. (2015) 16:925-34. doi: 10.1590/S1519-99402015000400016

10. Soto-Blanco B, Melo MM. Apidismo. Cadernos Técnicos de Veterinária e Zootecnia. (2014) 75:71-5.

11. Schmidt JO. Clinical consequences of toxic envenomations by hymenoptera. Toxicon. (2018) 150:96-104. doi: 10.1016/j.toxicon.2018.05.013

12. Veado HC, Conceição RS, Nogueira K, Fino T, Silva AS, Castro MB, et al. Massive africanized honeybee stings in two hair sheep and a mare. Toxicon. (2020) 177:35-40. doi: 10.1016/j.toxicon.2020.01.015

13. Pascoal A, Estevinho MM, Choupina AB, Sousa-Pimenta M, Estevinho LM. An overview of the bioactive compounds, therapeutic properties and toxic effects of apitoxin. Food Chem Toxicol. (2019) 134:110864. doi: 10.1016/j.fct.2019.110864

14. Medeiros CR, França FOS. Acidentes por abelhas e vespas. In: Cardoso JLC, França FOS, Wen FH, Málaque CMS, Haddad V Jr, editors. Animais Peçonhentos no Brasil - Biologia, Clínica e Terapêutica dos Acidentes, 2nd ed. São Paulo, Brazil: Sarvier (2009). p. 259-67.

15. Pucca MB, Cerni FA, Oliveira IS, Jenkins TP, Argemí L, Sørensen CV, et al. Bee updated: current knowledge on bee venom and bee envenoming therapy. Front Immunol. (2019) 10:2090. doi: 10.3389/fimmu.2019.02090

16. Chen J, Guan SM, Sun W, Fu H. Melittin, the major painproducing substance of bee venom. Neurosci Bull. (2016) 32:265-72. doi: 10.1007/s12264-016-0024-y

17. Memariani H, Memariani M, Shahidi-Dadras M, Nasiri S, Akhavan MM, Moravvej H. Melittin: from honeybees to superbugs. Appl Microbiol Biotechnol. (2019) 103:3265-76. doi: 10.1007/s00253-019-09698-y

18. Memariani H, Memariani M, Moravvej H, Shahidi-Dadras M. Melittin: a venom-derived peptide with promising anti-viral properties. Eur J Clin Microbiol Infect Dis. (2020) 39:5-17. doi: 10.1007/s10096-019-03674-0

19. Gajski G, Garaj-Vrhovac V. Mellitin: a lytic peptide with anticancer properties. Environ Toxicol Pharmacol. (2013) 36:697705. doi: 10.1016/j.etap.2013.06.009

20. Hood JL, Jallouk AP, Campbell N, Ratner L, Wickline SA. Cytolytic nanoparticles attenuate HIV-1 infectivity. Antivir Ther. (2013) 18:95103. doi: 10.3851/IMP2346

21. Maher S, Feighery L, Brayden DJ, McClean S. Melittin as a permeability enhancer II: in vitro investigations in human mucous secreting intestinal monolayers and rat colonic mucosae. Pharm Res. (2007) 24:134656. doi: 10.1007/s11095-007-9246-Z

22. Maher S, McClean S. Melittin exhibits necrotic cytotoxicity in gastrointestinal cells which is attenuated by cholesterol. Biochem Pharmacol. (2008) 75:110414. doi: 10.1016/j.bcp.2007.10.029

23. Abu-Zinadah O, Rahmy T, Alahmari A, Abdu F. Effect of melittin on mice stomach. Saudi J Biol Sci. (2014) 21:99-108. doi: 10.1016/j.sjbs.2013.08.002

24. Voos P, Yazar M, Lautenschläger R, Rauh O, Moroni A, Thiel G. The small neurotoxin apamin blocks not only small conductance $\mathrm{Ca} 2+$ activated $\mathrm{K}+$ channels (SK type) but also the voltage dependent Kv1.3 channel. Eur Biophys J. (2017) 46:517-23. doi: 10.1007/s00249-0161196-0
25. Lee G, Bae H. Bee venom phospholipase A2: yesterday's enemy becomes today's friend. Toxins. (2016) 8:48. doi: 10.3390/toxins 8020048

26. Muller UR. Hymenoptera venom proteins and peptides for diagnosis and treatment of venom allergic patients. Inflamm Allergy Drug Targets. (2011) 10:420-8. doi: 10.2174/187152811797200704

27. Dutilh CE, Groger W. Improvement of product attributes of mayonnaise by enzymic hydrolysis of egg yolk with phospholipase A2. J Sci Food Agric. (1981) 32:451-8. doi: 10.1002/jsfa.2740320505

28. De Maria L, Vind J, Oxenbøll KM, Svendsen A, Patkar S. Phospholipases and their industrial applications. Appl Microbiol Biotechnol. (2007) 74:290300. doi: 10.1007/s00253-006-0775-x

29. Helbling A, Peter CH, Berchtold E, Bogdanov S, Müller U. Allergy to honey: relation to pollen and honey bee allergy. Allergy. (1992) 47:419. doi: 10.1111/j.1398-9995.1992.tb02248.x

30. Mourre C, Lazdunski M, Jarrard LE. Behaviors and neurodegeneration induced by two blockers of $\mathrm{K}+$ channels, the mast cell degranulating peptide and dendrotoxin I. Brain Res. (1997) 762:223-7. doi: 10.1016/S0006-8993(97)00481-2

31. Fernández-Reina A, Urdiales JL, Sánchez-Jiménez F. What we know and what we need to know about aromatic and cationic biogenic amines in the gastrointestinal tract. Foods. (2018) 7:145. doi: 10.3390/foods7090145

32. Feddern V, Mazzuco H, Fonseca FN, de Lima GJMM. A review on biogenic amines in food and feed: toxicological aspects, impact on health and control measures. Anim Prod Sci. (2019) 59:608-18. doi: 10.1071/AN18076

33. Oliveira FA, Guimarães JV, Reis MA, Teixeira VP. Acidente humano por picadas de abelhas africanizadas. Rev Soc Bras Med Trop. (2000) 33:4035. doi: 10.1590/S0037-86822000000400012

34. Soto-Blanco B, Melo MM. Acidentes por picadas de abelhas. Cadernos Técnicos de Saúde da FASEH. (2018) 5:23-5.

35. Mytas DZ, Stougiannos PN, Zairis MN, Tsiaousis GZ, Foussas SG, Hahalis GN, et al. Acute anterior myocardial infarction after multiple bee stings. A case of kounis syndrome. Int J Cardiol. (2009) 134:e12931. doi: 10.1016/j.ijcard.2008.01.050

36. Karasu E, Minareci K. Myocardial infarction following a bee sting: an example of type II Kounis syndrome. Int J Cardiol. (2011) 148:3824. doi: 10.1016/j.ijcard.2010.10.099

37. Nittner-Marszalska M, Kopeć A, Biegus M, Kosińska M, Obojski A, Pawłowicz $\mathrm{R}$, et al. Non-ST segment elevation myocardial infarction after multiple bee stings. A case of "delayed" kounis II syndrome? Int J Cardiol. (2013) 166:e62-5. doi: 10.1016/j.ijcard.2013.01.062

38. Aminiahidashti H, Laali A, Samakoosh AK, Gorji AM. Myocardial infarction following a bee sting: a case report of kounis syndrome. Ann Card Anaesth. (2016) 19:375-8. doi: 10.4103/0971-9784.179626

39. Ceyhan C, Ercan E, Tekten T, Kirilmaz B, Onder R. Myocardial infarction following a bee sting. Int J Cardiol. (2001) 80:2513. doi: 10.1016/S0167-5273(01)00477-6

40. Senthilkumaran S, David SS, Menezes RG, Thirumalaikolundusubramanian P. Acute myocardial infarction triggered by bee sting: an alternative view. Emerg Med Australas. (2013) 25:615. doi: 10.1111/1742-6723.12140

41. Zhang S, Liu Y, Ye Y, Wang XR, Lin LT, Xiao LY, et al. Bee venom therapy: potential mechanisms and therapeutic applications. Toxicon. (2018) 148:6473. doi: 10.1016/j.toxicon.2018.04.012

42. Cherniack EP, Govorushko S. To bee or not to bee: the potential efficacy and safety of bee venom acupuncture in humans. Toxicon. (2018) 154:748. doi: 10.1016/j.toxicon.2018.09.013

43. Yang W, Hu FL, Xu XF. Bee venom and SARS-CoV-2. Toxicon. (2020) 181:69-70. doi: 10.1016/j.toxicon.2020.04.105

44. Brown TC, Tankersley MS. The sting of the honeybee: an allergic perspective. Ann Allergy Asthma Immunol. (2011) 107:463-70. doi: 10.1016/j.anai.2011.09.015

45. Brown TC. Reactions to honeybee stings: an allergic prospective. Curr Opin Allergy Clin Immunol. (2013) 13:365-71. doi: 10.1097/ACI.0b013e3283625144

46. Elieh Ali Komi D, Shafaghat F, Zwiener RD. Immunology of bee venom. Clin Rev Allergy Immunol. (2018) 54:386-96. doi: 10.1007/s12016-017-8597-4

47. Cifuentes L. Allergy to honeybee ... not only stings. Curr Opin Allergy Clin Immunol. (2015) 15:364-8. doi: 10.1097/ACI.0000000000000191

48. Pereira Santos MC, Pedro E, Spínola Santos A, Branco Ferreira M, Palma Carlos ML, Palma Carlos AG. Immunoblot studies in allergic patients to 
hymenoptera venom before and during immunotherapy. Eur Ann Allergy Clin Immunol. (2005) 37:273-8.

49. Thorp RW. The collection of pollen by bees. In: Dafni A, Hesse M, Pacini E, editors. Pollen and Pollination. Viena, Austria: Springer-Verlag Wien (2000). p. 211-23. doi: 10.1007/978-3-7091-6306-1_11

50. Wappler T, Labandeira CC, Engel MS, Zetter R, Grímsson F. Specialized and generalized pollen-collection strategies in an ancient bee lineage. Curr Biol. (2015) 25:3092-8. doi: 10.1016/j.cub.2015.09.021

51. Danner N, Keller A, Härtel S, Steffan-Dewenter I. Honey bee foraging ecology: season but not landscape diversity shapes the amount and diversity of collected pollen. PLoS ONE. (2017) 12:e0183716. doi: 10.1371/journal.pone. 0183716

52. Ricigliano VA, Fitz W, Copeland DC, Mott BM, Maes P, Floyd AS, et al. The impact of pollen consumption on honey bee (Apis mellifera) digestive physiology and carbohydrate metabolism. Arch Insect Biochem Physiol. (2017) 96:e21406. doi: 10.1002/arch.21406

53. Komosinska-Vassev K, Olczyk P, Kazmierczak J, Mencner L, Olczyk K. Bee pollen: chemical composition and therapeutic application. Evid Based Complement Altern Med. (2015) 2015:297425. doi: 10.1155/2015/297425

54. Denisow B, Denisow-Pietrzyk M. Biological and therapeutic properties of bee pollen: a review. J Sci Food Agric. (2016) 96:4303-9. doi: 10.1002/jsfa.7729

55. Nonotte-Varly C. Allergenicity of artemisia contained in bee pollen is proportional to its mass. Eur Ann Allergy Clin Immunol. (2015) 47:218-24.

56. Geyman JP. Anaphylactic reaction after ingestion of bee pollen. J Am Board Fam Pract. (1994) 7:250-2.

57. Pitsios C, Chliva C, Mikos N, Kompoti E, Nowak-Wegrzyn A, KontouFili K. Bee pollen sensitivity in airbone pollen allergic individuals. Ann Allergy Asthma Immunol. (2006) 97:703-6. doi: 10.1016/S1081-1206(10) 61104-0

58. Martín-Muñoz MF, Bartolome B, Caminoa M, Bobolea I, Ara MC, Quirce S. Bee pollen: a dangerous food for allergic children. Identification of responsible allergens. Allergol Immunopathol. (2010) 38:263-5. doi: 10.1016/j.aller.2009.12.003

59. Nonotte-Varly C. Allergenicity of gramineae bee-collected pollen is proportional to its mass but is highly variable and depends on the members of the gramineae family. Allergol Immunopathol (Madr). (2016) 44:23240. doi: 10.1016/j.aller.2015.05.003

60. Shahali Y. Allergy after ingestion of bee-gathered pollen: influence of botanical origins. Ann Allergy Asthma Immunol. (2015) 114:2501. doi: 10.1016/j.anai.2014.11.009

61. Choi JH, Jang YS, Oh JW, Kim CH, Hyun IG. Bee pollen-induced anaphylaxis: a case report and literature review. Allergy Asthma Immunol Res. (2015) 7:513-7. doi: 10.4168/aair.2015.7.5.513

62. Greenberger PA, Flais MJ. Bee pollen-induced anaphylactic reaction in an unknowingly sensitized subject. Ann Allergy Asthma Immunol. (2001) 86:23942. doi: 10.1016/S1081-1206(10)62698-1

63. Baek HS, Jeong JW, Lee HB, Kwon JW. Molecular sensitization patterns in birch pollen-sensitized Korean children according to the presence of oral allergy syndrome. Medicine. (2020) 99:e19469. doi: 10.1097/MD.00000000000 19469

64. Wassmann-Otto A, Heratizadeh A, Wichmann K, Werfel T. Birch pollenrelated foods can cause late eczematous reactions in patients with atopic dermatitis. Allergy. (2018) 73:2046-54. doi: 10.1111/all.13454

65. Asero R, Abbadessa S, Aruanno A, Barilaro G, Barzaghi C, Bignardi D, et al. Detection of gibberellin-regulated protein (peamaclein) sensitization among italian cypress pollen-sensitized patients. J Investig Allergol Clin Immunol. (2020). doi: 10.18176/jiaci.0542. [Epub ahead of print].

66. Charpin D, Pichot C, Belmonte J, Sutra, JP, Zidkova J, et al. Cypress pollinosis: from tree to clinic. Clin Rev Allergy Immunol. (2019) 56:17495. doi: 10.1007/s12016-017-8602-y

67. Yonekura S, Gotoh M, Kaneko S, Kanazawa K, Takeuji Y, Okubo K, et al. Treatment duration-dependent efficacy of Japanese cedar pollen sublingual immunotherapy: evaluation of a phase II/III trial over three pollen dispersal seasons. Allergol Int. (2019) 68:494-505. doi: 10.1016/j.alit.2019.05.002

68. Bedolla-Barajas M, Kestler-Gramajo A, Alcalá-Padilla G, Morales-Romero J. Prevalence of oral allergy syndrome in children with allergic diseases. Allergol Immunopathol (Madr). (2017) 45:127-33. doi: 10.1016/j.aller.2016. 04.017
69. Lam HCY, Turner PJ, Hemming D, Jarvis DL. Seasonality of food-related anaphylaxis admissions and associations with temperature and pollen levels. J Allergy Clin Immunol Pract. (2020) doi: 10.1016/j.jaip.2020.07.032. [Epub ahead of print].

70. Vara A, Fernández-González M, Aira MJ, Rodríguez-Rajo FJ. Oleaceae crossreactions as potential pollinosis cause in urban areas. Sci Total Environ. (2016) 542(Pt A):435-40. doi: 10.1016/j.scitotenv.2015.10.107

71. Ramon GD, Barrionuevo LB, Viego V, Vanegas E, Felix M, CherrezOjeda I. Sensitization to subtropical grass pollens in patients with seasonal allergic rhinitis from Bahia Blanca, Argentina. World Allergy Organ J. (2019) 12:100062. doi: 10.1016/j.waojou.2019.100062

72. Kailaivasan TH, Timbrell VL, Solley G, Smith WB, McLean-Tooke A, van Nunen S, et al. Biogeographical variation in specific IgE recognition of temperate and subtropical grass pollen allergens in allergic rhinitis patients. Clin Transl Immunology. (2020) 9:e01103. doi: 10.1002/cti2.1103

73. Aud-In S, Somkid K, Songnuan W. Group-1 grass pollen allergens with near-identical sequences identified in species of subtropical grasses commonly found in Southeast Asia. Medicina. (2019) 55:193. doi: $10.3390 /$ medicina55050193

74. Joubert AI, Geppert M, Johnson L, Mills-Goodlet R, Michelini S, Korotchenko E, et al. Mechanisms of particles in sensitization, effector function and therapy of allergic disease. Front Immunol. (2020) 11:1334. doi: 10.3389/fimmu.2020.01334

75. Melerbo-Souza DT, Toledo VAA, Couto LA, Nogueira-Couto RH. Uso da tela excluidora de rainha no alvado e seus efeitos na atividade de coleta e no desenvolvimento de colônias de Apis mellifera. Acta Sci Anim Sci. (1998) 20:383-6.

76. Crailsheim K, Schneider L, Hrassnigg N. Pollen consumption and utilization in worker honeybees (Apis mellifera carnica): dependence on individual age and function. I Insect Physiol. (1992) 38:409-19. doi: 10.1016/0022-1910(92)90117-V

77. Mesquita LX, Maracajá PB, Sakamoto SM, Soto-Blanco B. Toxic evaluation in honey bees (Apis mellifera) of pollen from selected plants from the semiarid region of Brazil. J Apic Res. (2010) 49:265-9. doi: 10.3896/IBRA.1. 49.3.06

78. Vale da Silva C, Mesquita LX, Maracajá PB, Soto-Blanco B. Toxicity of Mimosa tenuiflora pollen to africanized honey bees (Apis mellifera L.). Acta Sci Vet. (2010) 38:161-3. doi: 10.22456/1679-9216.16615

79. Assis Junior EM, Fernandes IMS, Santos CS, Mesquita LX, Pereira RA, Maracajá PB, et al. Toxicity of castor bean (Ricinus communis) pollen to honeybees. Agric Ecosyst Environ. (2011) 141:221-3. doi: 10.1016/j.agee.2011.02.010

80. Melo IRBV, Lages MCC, Santos DP, Maracajá PB, Rodrigues RAPF, Soto-Blanco B. The pollen of Caesalpinia pyramidalis Tul. is toxic to honeybees (Apis mellifera). Anthropod Plant Interact. (2013) 7: 4636. doi: 10.1007/s11829-013-9254-3

81. Jacquemart AL, Buyens C, Hérent MF, Quetin-Leclercq J, Lognay G, Hance $T$, et al. Male flowers of aconitum compensate for toxic pollen with increased floral signals and rewards for pollinators. Sci Rep. (2019) 9:16498. doi: 10.1038/s41598-019-53355-3

82. Boppré M, Colegate SM, Edgar JA, Fischer OW. Hepatotoxic pyrrolizidine alkaloids in pollen and drying-related implications for commercial processing of bee pollen. J Agric Food Chem. (2008) 56:5662-72. doi: 10.1021/jf800568u

83. Kempf M, Heil S, Hasslauer I, Schmidt L, von der Ohe K, Theuring C, et al. Pyrrolizidine alkaloids in pollen and pollen products. Mol Nutr Food Res. (2010) 54:292-300. doi: 10.1002/mnfr.200900289

84. Kempf M, Reinhard A, Beuerle T. Pyrrolizidine alkaloids (PAs) in honey and pollen-legal regulation of PA levels in food and animal feed required. Mol Nutr Food Res. (2010) 54:158-68. doi: 10.1002/mnfr.200 900529

85. Kast C, Kilchenmann V, Reinhard H, Droz B, Lucchetti MA, Dübecke A, et al. Chemical fingerprinting identifies Echium vulgare, Eupatorium cannabinum and Senecio spp. as plant species mainly responsible for pyrrolizidine alkaloids in bee-collected pollen. Food Addit Contam A Chem Anal Control Expo Risk Assess. (2018) 35:316-27. doi: 10.1080/19440049.2017.13 78443

86. Gottschalk C, Kaltner F, Zimmermann M, Korten R, Morris O, Schwaiger K, et al. Spread of Jacobaea vulgaris and occurrence of pyrrolizidine alkaloids 
in regionally produced honeys from Northern Germany: inter- and intra-site variations and risk assessment for special consumer groups. Toxins. (2020) 12:E441. doi: 10.3390/toxins12070441

87. Stegelmeier BL, Colegate SM, Brown AW. Dehydropyrrolizidine alkaloid toxicity, cytotoxicity, and carcinogenicity. Toxins. (2016) 8:E356. doi: 10.3390/toxins8120356

88. Schramm S, Köhler N, Rozhon W. Pyrrolizidine alkaloids: biosynthesis, biological activities and occurrence in crop plants. Molecules. (2019) 24:E498. doi: 10.3390/molecules24030498

89. Stoner KA, Eitzer BD. Using a hazard quotient to evaluate pesticide residues detected in pollen trapped from honey bees (Apis mellifera) in connecticut. PLOS ONE. (2013) 8:e77550. doi: 10.1371/journal.pone.0077550

90. Kasiotis KM, Anagnostopoulos C, Anastasiadou P, Machera K. Pesticide residues in honeybees, honey and bee pollen by LCMS/MS screening: reported death incidents in honeybees. Sci Total Environ. (2014) 485-486:633-42. doi: 10.1016/j.scitotenv.2014. 03.042

91. Muli E, Kilonzo J, Dogley N, Monthy G, Kurgat J, Irungu J, et al. Detection of pesticide residues in selected bee products of honeybees (Apis mellifera L.) colonies in a preliminary study from seychelles archipelago.
Bull Environ Contam Toxicol. (2018) 101:451-7. doi: 10.1007/s00128-0182423-4

92. Pinheiro CE, Oliveira FS, Oloris SS, da Silva JA, Soto-Blanco B. Pesticide residues in honey from stingless bee Melipona subnitida (Meliponini, Apidae). J Apic Sci. (2020) 64:29-36. doi: 10.2478/jas-2020-0010

93. Brazil, Ministério da Saúde, Agência Nacional de Vigilância Sanitária. Resolução-RDC $\mathrm{N}^{\circ}$ 36, de 16 de agosto de 2010. Diário Oficial da União (2010) 18/08/10.

Conflict of Interest: The authors declare that the research was conducted in the absence of any commercial or financial relationships that could be construed as a potential conflict of interest.

Copyright (c) 2020 Marinho and Soto-Blanco. This is an open-access article distributed under the terms of the Creative Commons Attribution License (CC BY). The use, distribution or reproduction in other forums is permitted, provided the original author(s) and the copyright owner(s) are credited and that the original publication in this journal is cited, in accordance with accepted academic practice. No use, distribution or reproduction is permitted which does not comply with these terms. 